\title{
Plurality and Religious Tolerance in Islam
}

\author{
Prof Wilson Hassan Nandwa \\ Umma University - Kenya
}

doi: 10.19044/esj.2016.v12n32p314 URL:http://dx.doi.org/10.19044/esj.2016.v12n32p314

\begin{abstract}
Islam is a divine religion with comprehensive teachings and guidance revealed to Muhammad, may peace and blessing of Allah be upon him, to guide mankind in matters of faith, rituals and inter human relations. Therefore Muslims believe that they are the custodians of the truth and all other persons professing faiths other than Islam are doomed unless they embrace Islam before their death. It is also a fact that the adherents of other religions also believe that their faiths are exclusively the truth and other persons are doomed unless they profess that faith and denounce theirs and this applies to Muslims too. In such circumstances a Muslim may be tempted to impose his faith on non-Muslims, after all, he shall be imposing the truth on them which is in their best interest. The Prophet, may peace and blessings of Allah be upon him, was keen to convert non- Muslims to Islam even at his own detriment. Allah in several verses continuously reminded His Messenger that his duty is just to convey the message and that he has no authority over people to force them to embrace Islam; and also declared that there is no compulsion in the religion, therefore people should embrace the faith of their choice. Moreover, Allah enjoins Muslims to co-operate and interact with people of other faiths in good things and in fear of Allah, meaning in obedience of Allah. Despite of the misunderstanding between Muslims and non-Muslims and the bad things done to Muslims by nonMuslims previously; Muslims should not oppress non-Muslims and infringe on their rights, to the contrary, they should treat them with justice and avail to them their rights and opportunities. At the same time, Allah declared that he does not prohibit Muslims from doing good to non-Muslims who are not fighting or oppressing Muslims because Islam is treating people with justice and being kind and humble. On the other side Muslims were at war with non-Muslim powers since the inception of Islam in the Arabian Peninsula. Many verses in the Holy Quran were revealed to address the state of war requiring Muslims to delink themselves from their enemies and fight fearlessly employing all means and resources in their war. Similarly, several traditions of the Prophet, may peace and blessings of Allah be upon him, referred to this situation of war and asked Muslims to fight and combat these
\end{abstract}


non-Muslims enemies with all efforts. If these verses and traditions are interpreted out of their context, they shall portray Islam as a religion of intolerance and as a system that does not recognize diversity and plurality of human being yet, plurality is the beauty of the World. In this paper, we shall explore the verses and traditions on this subject and strive to interpret them against the background of their revelation and context in order to determine the parameters of Plurality in Islam. In this paper; Ridda refers to denouncing Muslim faith, Surah means a chapter in the Holy Quran and Hadith, Tradition or Sunnah refers to the teachings of Prophet Muhammad, peace and blessing of Allah be upon him.

Keywords: Muslims, religion, Holy Quran

\section{Introduction}

Tolerance among persons of different faiths is the key to national integration and international peace and security to enhance development at all levels. Throughout the human history instance of intolerance have been experienced leading to shading of innocent blood and destruction of property and other resources, and worse still we witness some religious groups emerging with new discoveries of interpretations of the religious text across different faiths threating the tolerance and peaceful co-existence that has been achieved after long struggle. The emergence of Al-Qaida, ISIS, Shabaab and Boko Haram just to mention few has attracted International attention and concern, however many questions remain unanswered awaiting academic efforts and attempts to disclose the truth behind this phenomenon. Many scholars both Muslims and non- Muslims have attempt to address the phenomenon of intolerance with is Islamic based with many of them addressing themselves to noble verses of the Holy Quran advocating tolerance among people of different faiths, but most of them left out instances where a Muslim converts to another religion other than Islam. For instance Marmaduke Pickhall (2016) urged that the Western World did not know religious tolerance until secularism was adopted whereas victims of that intolerance found safe havens in the Muslim World.

\section{The Nature of the World}

The World in which we live and to it our livelihoods are attached is controlled by rules and regulated by principles which we may refer to as rule of nature. The Scientific Research only discloses these rules and principles to enable man manipulate his environment in form of development to make the World a better place for human life. The Technological development, medical advancement just to name few are evidence of the discovered rules 
and principles of nature and how useful the discovered information can be used to improve human life on the Earth.

If we look at the nature around us, we find it full of plurality and diversity in all fields and spheres. Take the example of the animal kingdom with herbivorous, carnivorous and omnivorous and the three co-exist in the same kingdom. It is clear that the herbivorous understand that the carnivorous are their enemies since they constitute their food, therefore the nature has conferred on them defence mechanisms such as the ability to run fast, ability to throw thorns at the enemy, the ability to emit awful smells to scare away the enemy, the ability to fight back physically as in case of an elephant and buffalo and so on and so forth. These animals exist in the same kingdom each playing it role in the habitant with one killing the other for either food or in its own defence such as a lion being killed by buffalos in an aborted hurting adventure. We infer from the animal kingdom that coexistence in plurality is a rule of nature. We further infer that animals had no choice to exist in their present form and therefore they shall not be accountable for their being in this form. Moreover animals lack the intellect for accountability besides freedom of choice rendering them not accountable for their deeds.

\section{The Devine Freedom for Human Beings}

Human beings have been granted freedom of choice beside the intellect to appreciate and discern what is good and what is bad. This is the basis of accountability of human beings in both criminal and civil matters although the standards are lowered in civil matters to accommodate acts emanating from negligence and even accidental events inflicting injuries on innocent persons. The natural plurality of human beings in terms of races, tribe, clan, colour, sex, origin and others, is purely a reality of nature and therefore do not attract any liability and should be treated just like the animal kingdom. Accordingly, it shall be wrong to discriminate between human being within those lines, and co-existence is therefore inevitable.

Human beings are social creatures and exist within a social setting which demands a set of rules to regulate the behaviours of individuals to avoid conflict and regulate the competing interests and desires of the individuals. This is the basis of laws and the justification of enacting regulations in any given society.

To acknowledge this fact the Prophet, May peace and blessing of Allah be upon him, said:

"If there people go out on a journey they must appoint one of them as their leader"(Abu Dawud 4: 2608)

It is therefore justified for the society to enact laws regulating the behaviour and conduct of individuals in that society; however such 
legislations are limited by the doctrine of human rights and good governance, to the effect that no legislation should take away the rights and freedoms of the people except to the extend to protecting the rights of others and justifiable in a democratic society. Others scholars may argue that the rights and freedoms are guaranteed to the extent that is permitted by the law or legislations, but such argument is misplaced since it gives an impression that human rights and freedoms are privileges granted by the makers of legislations, yet human rights and fundamental freedoms are inherent entitlement of the people.

Islamic law just like other legal systems regulate the behaviours of individuals in the society subject to it by creating both criminal and civil liability for the best interest of well-being of the society. It is worth noting that the legal mechanism only holding individuals for the material conduct that has manifested in an act or omission not the acts of the heart. In other words, the beliefs and faiths per se do not attract criminal or civil liability unless they entail a material behaviour or conduct that infringe on the rights of others or contravene the law which purports to protect the rights of others and the society at large.

The Religious freedom is anchored on this fact, to allow every individual to profess the faith of his own choice and manifest that faith in a manners that respects the rights of others that the wellbeing of the society.

\section{International Law on Religious Freedom}

The Universal Declaration on Human Rights at Article 18 provides:

Everyone has the right to freedom of thought, conscience and religion; this right includes freedom to change his religion or belief, and freedom, either alone or in community with other and in public or private, to manifest his religion or belief in teaching, practice, worship and observance.

Whereas the International Convention on Civil and Political Rights at article 18 provides:

1. Everyone shall have the right to freedom of thought, conscience and religion. This right shall include freedom to have or to adopt a religion or belief of his choice, and freedom, either individually or in community with others and in public or private, to manifest his religion or belief in worship, observance, practice and teaching.

2. No one shall be subject to coercion which would impair his freedom to have or to adopt a religion or belief of his choice.

3. Freedom to manifest one's religion or beliefs may be subject only to such limitations as are prescribed by law and are necessary to protect public safety, order, health, or morals or the fundamental rights and freedoms of others. 
4. The States Parties to the present Covenant undertake to have respect for the liberty of parents and, when applicable, legal guardians to ensure the religious and moral education of their children in conformity with their own convictions.

\section{Islam Condemns Religious Persecution}

Allah, the Exalted, has condemned the societies that failed to grant the religious freedoms such as the society of the people of the cave, Kahf, who persecuting Muslims which act made the youth to flee to the cave, Kahf where they stayed for three hundred years and extended by nine more years.

Similarly, when people of Ukhdoud, dag the trenches and blazed fire in them in order to burn Muslims alive because they had decided to believe in Allah, Allah condemned their act which was infringing on the religious freedoms.

The Prophet Ibrahim was thrown in fire to burn alive because he had decided not to believe in the idols, fortunately, by the mercy of Allah, he did not burn to their disappointment.

The disciples of Issa, Jesus, were being persecuted the Roman Rulers for their religious beliefs, and Saul himself confessed that he persecuting the followers of Jesus before adopting a new name; Paul. Moreover the Romans planned to kill Issa, Jesus, for his religious beliefs.

The Prophet Muhammad may peace and blessing of Allah be upon him, and his companions were persecuted in Mecca just because they decided to believe in Islam and disbelieve in the idols of Mecca. The persecution resulted in the migration to Ethiopian then eventually to Medina.

From the biography of the Prophet we cannot find any unlawful act done by his companions to warranty any punishment; by analysing the response of Ja'far bin Abi Talib to the allegations of Quresh before King of Abyssinia Nagus alias Najashy claiming that they had emerged with a new religion, divided the Meccan Community, insulting their idols, Ja'far summarized the teachings of Islam in few words and no element of crime was disclosed. Consequently, King Nagus sent away the Quresh delegation and grants Muslims asylum.

Ja'far then gave a speech presenting Islam to the Negus (Imam Abu al-Fida Ismai'l bin Kathir 2: 7). He said:

"O King! We were ignorant people and we lived like wild animals. The strong among us lived by preying upon the weak. We obeyed no law and we acknowledged no authority save that of brute force. We worshipped idols made of stone or wood, and we knew nothing of human dignity. And then God, in His Mercy, sent to us His Messenger who was himself one of us. We knew about his truthfulness and his integrity. His character was exemplary, and he 
was the most well-born of the Arabs. He invited us toward the worship of One God, and he forbade us to worship idols. He exhorted us to tell the truth, and to protect the weak, the poor, the humble, the widows and the orphans. He ordered us to show respect to women, and never to slander them. We obeyed him and followed his teachings. Most of the people in our country are still polytheists, and they resented our conversion to the new faith which is called Islam. They began to persecute us and it was in order to escape from persecution by them that we sought and found sanctuary in your kingdom."

History tells us that Muslims have been victims of religious freedoms and on the receiving end of tyrants who did not acknowledge religious plurality or tolerate any religion other than the religion of their choice.

Islam from its early days in Mecca, the Prophet, may peace and blessings of Allah be upon him was instructed that his mission was to deliver the message of Islam in the best way possible and people has the free choice of either accepting the message by embracing Islam or disbelieving in it all together; whichever way they choose it is Allah who shall hold them accountable in the day of Judgment. The Prophet has no authority over them to force them to believe or even subject them to any punishment by virtue of their disbelieving in him and his message.

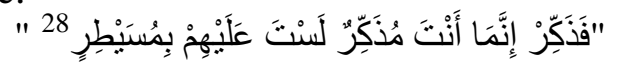

"Remind, verily you are the reminder, you have no authority over them” (Quran: Al-Ghashiya: 22)

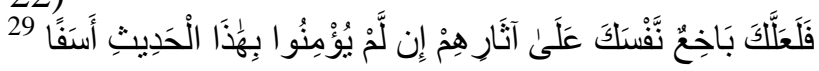

"You are just about to destroy yourself following their disbelief in this story"(Quran: Al-Kahf: 6)

These principles were very important for the Prophet, may peace and blessings of Allah be upon him, because he was sure that his message was the truth and his religion was the correct faith, this may lead him to attempt forcing people to make the correct decision, moreover he may be disappointed to see his people making a wrong choice leading them to the Hell Fire. Because of these facts, Allah revealed the verses emphasizing the freedom of persons to make their own choice to believe in Islam or disbelieve in it and clarifying that the accountability on such decision lays with Allah not the Prophet.

When one of the companions of the Prophet, May peace and blessing of Allah be upon him, was keen to covert his son to be a Muslim, and almost 
forced him to make the correct decision in his opinion, Allah revealed this verse:

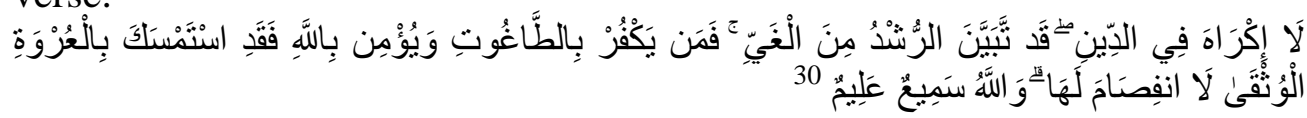

"There is no compulsion in religion. Verily, the right path has become distinct from the wrong path." (Quran: Al-Baqara: 226)

This verse in Surah Baqara provides for a general principle which has not been abrogated but any verse. The allegation that this verse was abrogated by the following verse in Surah Taubah is mispleased:

"Fight those who do not believe in Allah and the Last Day, and do not prohibit what Allah and His Messenger prohibit, until they pay Jizya in total submission" (Quran: At-Tauba:29)

This verse duels on the disbelievers who were at war with Muslims, in fact the entire Surah; Taubah duels on state of war whereby the disbeliever had breached the covenants with the Prophet, whereas the verse in Surah Baqara provides for a general principle during the peace time, before the disbelievers declare war on Muslims by virtue of the religion. We should observe here that Muslims were the ones who were being fought because of their religion not that Muslims fought the disbelievers to convert them to Islam. We further note that religious intolerance against Muslims did not end by the migration to Medina.

The tradition in which it is narrated that the Prophet may peace and blessing of Allah be upon him saying:

"It has been narrated on the authority of Abdullah bin. 'Umar that the Messenger of Allah said: I have been commanded to fight against people till they testify that there is no God but Allah, that Muhammad is the messenger of Allah, and they establish prayer, and pay Zakat and if they do it, their blood and property are guaranteed protection on my behalf except when justified by law, and their affairs rest with Allah" (Sahih Muslim 21)

This tradition was cited when Abu Bakar, may Allah be pleased with him, declared war on the apostates who although they were still professing Muslim faith, they declared disobedience of the authority of Abu Bakar manifesting in them declining to pay Zakah, besides those who had actually denounced Islamic faith such as Mussailama coupled with rebellion and disobedience of the authority of Abu Bakar. This tradition should be restricted in its interpretation to apply to rebellion against authorities just as the companions of the Prophet applied it to rebels against the authority Abu Bakar, therefore the traditions should not be construed to mean justification to wage war against non-Muslims with a view of compelling them to 
embrace Islam. This is light with the act of the Prophet, May peace and blessings of Allah be upon him, died and left his shield pledged with a Jew in Medina for food he had bought from him on credit. He, may peace and blessings of Allah be upon him co-existed in Medina with the Jew and even bought food from him on credit and pledged his shield instead of fighting him as the tradition apparently require from him.

Therefore the principle of religion tolerance provided for in the verse in Surah Baqarah, is upheld by the act of the Prophet himself, may peace and blessing of Allah be upon him.

When the Prophet may peace and blessings of Allah be upon him, migrate to Medina, he recognized the co-existence of Muslims with the different Jewish tribes and concluded an instrument for the co-existence in Medina. When the Jewish tribes breached their obligations, they were tried, convicted and sentenced according in line with the provisions of the law.

In fact Allah explicitly declares that He does not forbid Muslims from co-existing with non-Muslims who are not at war with Muslims in the following verse:

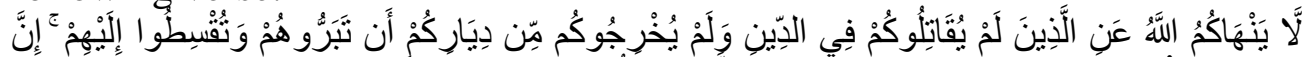

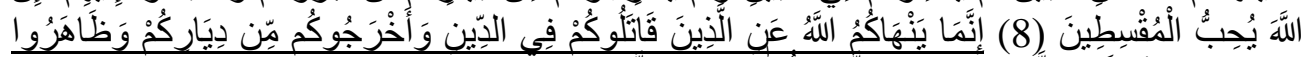

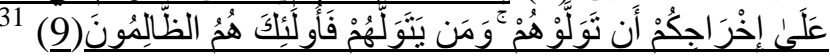
"Allah does not forbid you respecting those who have not made war against you on account of (your) religion, and have not driven you forth from your homes, that you show them kindness and deal with them justly; surely Allah loves the doers of justice"(Quran: Al-Mumtahina: 8-9)

The context of this verse discloses the Jewish tribe of Nadhir which had just breached its obligations under the Medina Covenant, after being sentenced to be evicted from Medina for their wrongs. Muslims could be attempted to loss trust of non-Muslims by generalizing the conduct of Nadhir tribe to apply to all non-Muslims. In this context Allah clarified that nonMuslims who accept to co-exist with Muslims are always welcomed to do so and Muslims are under obligation to respect them and treat them to just, good interaction.

Human beings regardless of their religions and faiths share the resources in the World across countries and regions, therefore co-operating premised on co-existence between people regardless of their faith. In this regard Allah declares as follows: 


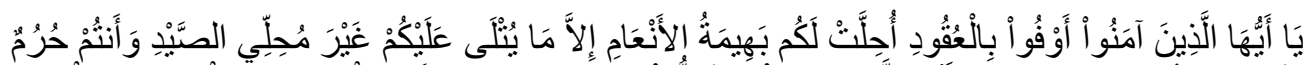

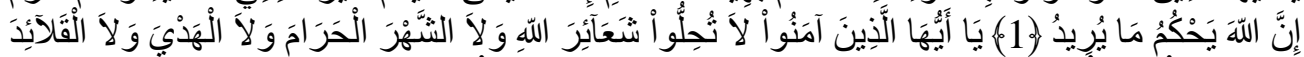

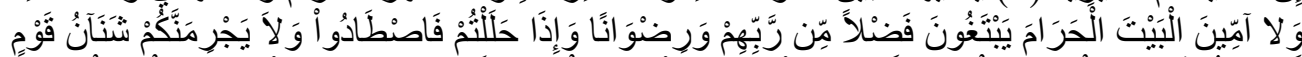

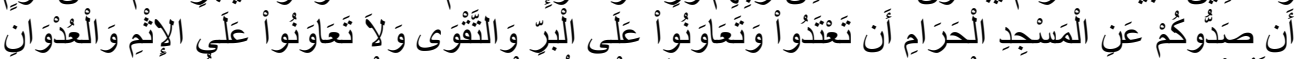

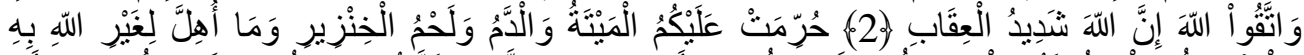

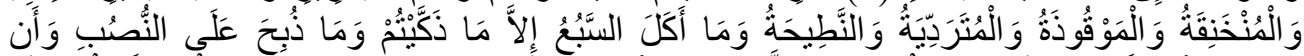

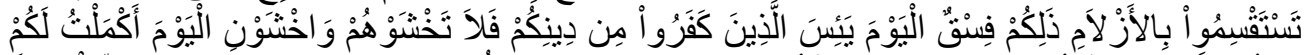

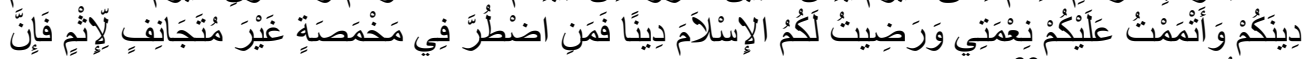

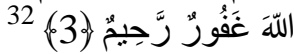

O you who believe, do not violate the rites instituted by GOD, nor the Sacred Months, nor the animals to be offered, nor the garlands marking them, nor the people who head for the Sacred Shrine (Ka'bah) seeking blessings from their Lord and approval. Once you complete the pilgrimage, you may hunt. Do not be provoked into aggression by your hatred of people who once prevented you from going to the Sacred Masjid. You shall cooperate in matters of righteousness and piety; do not cooperate in matters that are sinful and evil. You shall observe Allah. Allah is strict in enforcing retribution (Quran: Al-An'am: 2-3).

\section{The Offence of Ridda in Muslim Jurisprudence}

It is clear that Islam considers matters of faith as personal and only Allah shall hold people accountable on how they exercised this freedom, after all it is only Him who knows what faith the hearts conceal. However, the conduct which emanates from this faith must respect the rights of others and the wellbeing of the entire society. This is paradigm shift from the systems that prevailed in the early period of Islam. Whereas the Quresh, Persian and Roman systems did not tolerate other faiths, Islam declared religious freedom.

Our books of Islamic Criminal law provide for offence referred to as Ridda, which apparently refers to a Muslim denouncing Islam to embrace any other faith other than the Muslim faith. There is no explicit verse providing for this offense except the tradition narrating that the Prophet saying:

Narrated 'Abdullah: Allah's Apostle said, "The blood of a Muslim who confesses that none has the right to be worshipped but Allah and that I am His Apostle, cannot be shed except in three cases: In Qisas for murder, a married person who commits illegal sexual intercourse and the one who reverts from Islam (apostate) and leaves the Muslims." (Sahih Bukhari 9:83:17) 
There is a problem with this tradition since it provides for death penalty for the three persons only whereas Allah declares death penalty for banditry in Surah Maidah (Quran: Al-Maida: 33)

Could the narrator of the tradition have confused an apostate with a bandit in the tradition?

In amid of such confusion other authentic traditions confirm the death penalty for apostates; those are Muslims who denounce Islam.

Narrated Ikrima: Ali burnt some people and this news reached Ibn 'Abbas, who said, "Had I been in his place I would not have burnt them, as the Prophet said, 'Don't punish (anybody) with Allah's Punishment.' No doubt, I would have killed them, for the Prophet said, 'If somebody (a Muslim) discards his religion, kill him.' "(Sahih Bukhari 4:52:26)

The context of these traditions is lacking since the apparent meaning contravenes the verse which prohibit compulsion in matters of faith as seen herein before. The husband of Umi Habiba who converted to Christianity in Abyssinia, Ethiopia was not condemned to death. These traditions that provide for death penalty on those who convert from Islam could be having a context that associate with unlawful acts that justify the death penalty. It should be noted that Islam was being fought by non-Muslims and changing ours religion to the enemies' religion could be tantamount to changing ranks in a battle.

The companions of the Prophet, may peace be upon him, understood that the penalty for reverting from the Islamic faith is death as indicated in the following tradition:

Narrated Abu Burda: Abu Musa said, "I came to the Prophet along with two men (from the tribe) of Ash'ariyin, one on my right and the other on my left, while Allah's Apostle was brushing his teeth (with a Siwak), and both men asked him for some employment. The Prophet said, 'O Abu Musa (O 'Abdullah bin Qais!).' I said, 'By Him Who sent you with the Truth, these two men did not tell me what was in their hearts and I did not feel (realize) that they were seeking employment.' As if I were looking now at his Siwak being drawn to a corner under his lips, and he said, 'We never (or, we do not) appoint for our affairs anyone who seeks to be employed. But O Abu Musa! (or 'Abdullah bin Qais!) Go to Yemen."' The Prophet then sent Mu'adh bin Jabal after him and when Mu'adh reached him, he spread out a cushion for him and requested him to get down (and sit on the cushion). Behold: There was a fettered man beside Abu Musa. Mu'adh asked, "Who is this (man)?" Abu Musa said, "He was a Jew and became a Muslim and then reverted back to Judaism." Then Abu Musa requested Mu'adh to sit down but Mu'adh said, "I will not sit down till he has been killed. This is the judgment of Allah and His Apostle (for such 
cases) and repeated it thrice. Then Abu Musa ordered that the man be killed, and he was killed. Abu Musa added, "Then we discussed the night prayers and one of us said, 'I pray and sleep, and I hope that Allah will reward me for my sleep as well as for my prayers" (Sahih Bukhari 9:84:58)

The same tradition has another narration as follows:

Narrated Abu Musa: A man embraced Islam and then reverted back to Judaism. Mu'adh bin Jabal came and saw the man with Abu Musa. Mu'adh asked, "What is wrong with this (man)?" Abu Musa replied, "He embraced Islam and then reverted back to Judaism." Mu'adh said, "I will not sit down unless you kill him (as it is) the verdict of Allah and His Apostle (Sahih Bukhari 9:89:271)

This is also the understanding of Uthman bin Affan in the following narration:

Uthman ibn Affan narrated : Abu Umamah ibn Sahl said: We were with Uthman when he was besieged in the house. There was an entrance to the house. He who entered it heard the speech of those who were in the Bilat. Uthman then entered it. He came out to us, looking pale.

He said: They are threatening to kill me now. We said: Allah will be sufficient for you against them, Commander of the Faithful! He asked: Why kill me? I heard the Apostle of Allah (peace be upon him) say: It is not lawful to kill a man who is a Muslim except for one of the three reasons: Kufr (disbelief) after accepting Islam, fornication after marriage, or wrongfully killing someone, for which he may be killed.

I swear by Allah, I have not committed fornication before or after the coming of Islam, nor did I ever want another religion for me instead of my religion since Allah gave guidance to me, nor have I killed anyone. So for what reason do you want to kill me? (․ㅡu Dawud 39:4487)

Similarly Abu Dawud has narrated the hadith of Muadh bin Jabal in his book of Sunan Abi Dawud at hadith number 4354; however in another narration he narrated the hadith with variations in the text is different as follows:

It is narrated from Aisha saying that the Messenger of Allah, peace and blessing of Allah be up him, said: 'the blood of a person who is a Muslin proclaiming that there is none to be worshipped except Allah and Muhammad is His messenger except for three things: a man who commits zina after consummating a marriage for he is to be stoned to death, a man who goes out as a bandit, fighting Allah and His 
messenger for he is to be killed or crucified or sent to exile or he kills a soul for he is to be killed for that (Abu Dawud 6: 409: 4353)

It is clearly mentioned here that the third person whose killing is lawful is the bandit not a person who has denounced Islam.

To shade more light on the context of this traditions let us look at the following tradition:

It is narrated by bin Abbas that Abdullah bin Sa'ad bin Abi As-Sarah used to write for the Messenger of Allah, peace and blessing of Allah be up on him, then Satan misled him and he joined the disbelievers, non-Muslims, then the Messenger of Allah, peace and blessings of Allah be up on him, gave order for him to be killed on the day of conquer of Mecca, but he sought the protection of Uthman bin Affan and the Messenger of Allah accorded him the protection. (Abu Dawud 6: 414: 4359)

Abdullah who had converted from Islam was subjected to the provisions and rules of dealing with an enemy, and therefore when he hide at Uthman's place and asked his protection from being executed Uthman did exactly that and the Prophet approved his asylum and protection.

It means that traditions like this one:

“Whoever changes his religion kill him”, (Abu Dawud 6: 407: 4351) lack the true context of war and can only be properly interpreted against the background of war which prevailed the relations between Muslims and nonMuslims throughout the Muslim history.

It is in same spirit that the female Jew slave who used to insult the Prophet, peace and blessings of Allah be up on him, was executed by her master who was blind and when the matter was reported to the Prophet, peace and blessings of Allah be up on him, he acquitted the blind man from the murder charges, since she had committed an offence attracting a capital punishment and lost sanctity for her life or blood. (Abu Dawud 6:416: 43614362). Accordingly, it is submitted that the act of insulting the Prophet being a crime attracting a capital penalty, whoever shall denounce Islam and then commits such offence, shall face death penalty for that offence rather than mere change of his religion.

Given that the traditions cited as basis of Ridda offence are authentic with inconsistence of some narrations with the provisions of Quran in regard to exclusion of bandits, it is possible that the companions of the Prophet misunderstood the teachings of the Prophet under the influence of the preIslamic factors that took away the religious freedom from people leading to persecution of the early Muslims. They could have confused an apostate with a bandit as it appears in some of the narrations given that traditions are narrated on basis of what the narrator understood and not by the exact words of the Prophet, may peace and blessing of Allah be upon him. This may be 
supported by the classification of Imam Bukhari and Imam Muslim these traditions under the verdict for bandits and apostates, person who have denounced Islamic faith. It is also possible that the context of the traditions is war relating where to convert from Islamic faith implied supporting the enemy and joining his ranks. This line of thinking is further strengthened by the Jurisprudence of Hanafi Jurists who have discussed the provisions of Apostates within the chapter on International Relations of a Muslim State; referred to in Arabic as Siyar the plural of Sira. In the view of Hanafi Jurists, a woman Muslim who denounces Islamic faith is not executed, but held in the custody and forced to revert back to Islam otherwise held until death since the Prophet, peace and blessing of Allah be up on him, prohibit killing a woman in the battle filed unless she is fighting. (Sheikh Sarakhasi, 109 and Sheikh Al-Kasani,532). It is evident that the context of these provisions is the state of war which prevailed the relations between the Muslim State and the States that existed by then. In the light of this explanation, it can be understood why Swahabah, companions of the Prophet, during the reign of Abu Baker may pleasure of Allah upon him, launched war against the people who declined to pay Zakah as a sign of rebellion and referred to as apostates as discussed hereinbefore.

In the current World of Human Rights at both International and Domestic levels where States declare to protect the religious freedom and acknowledge the right of persons to profess new faiths and practice the teachings emanating from such faith, it would be absurd to present Islam as an ideology which advocates for the dark ages which saw people being persecuted for having adopted new faiths. Muslims themselves were victims of such violations in Mecca. In practice if non-Muslim communities decide to ban religious freedom therefore outlawing reversion to Islam in return of the Muslim community considering desertion of Islamic faith a crime of Ridda, it is Islam which will suffer because the number of non-Muslims reverting to Islam is much higher than just a handful of Muslims denouncing Islam for Christianity or other faiths.

It is therefore significant that the offense of Ridda should be reviewed further in light of the contemporary legal theories and ideologies of religious tolerance.

The right to religious freedom just like other rights is subject the respect of the rights of others, as much as a person may be entitled to profess the faith of his choice and be able to practice the teachings of that faith and manifest then in his private and public life, he may not infringe on the rights of others.

Allah the Exalted precludes Muslims from insulting those who worship other gods other than Allah or insult their gods. (Al-Anbiyah: 108) 


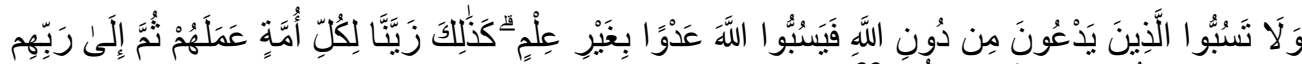

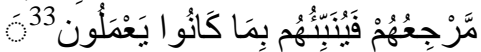

The religious freedom entails the right to propagate that faith to convince others to join you and manifest the faith together; however this right should be within the parameters of respect of others. In this regards Allah says:

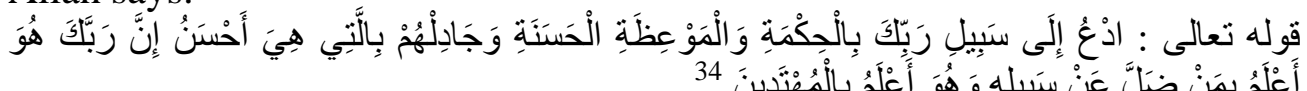

'Invite people to the path of your Lord with wisdom and good admonishing, and discuss with them by good argument, verily it is your Lord who knows better people who have gone astray from His path and He is knows better the guided people' (Suratil Nahl :125)

These guidelines ensure that the rights of other are respected in the process of propagating one's faith to win more followers.

Insulting one of the Prophets or Angels, desecrating the holy things such as Quran shall amount to blasphemy which is a criminal offence attracting capital punishment in the Holy Bible. This could be the concept of Ridda that Muslim Scholars interpreted it to include mere change of religion.

It is clear that Islam provides for religious plurality and regulates it in a manner that does not take away the religious freedom by forcing people to adopt it or encouraging Muslims to be hypocrites through threating them with capital punishment if they dare abandon the Muslim faith.

Now using the above principles of religious plurality in Islam, religious tolerance is possible moreover inter sect tolerance between the Shiite and Sunni is possible.

\section{Verses on war}

Suratul Tauba in its entirety was revealed in the context of war where Muslims were reluctant to fight people who had entered in peace truce with them before they breached their obligations, the Surah denounced the previous treaties with those enemies in line with the principle of reciprocate treatment. The chapter or Surah went ahead to give courage to Muslim soldiers to fight bravely in order to defeat the enemy

$$
\text { "قاتلوا الذين لا يؤمنون بالله و لا باليوم الآخر (Surati Tauba }
$$

'Fight those who do not believe in Allah or the last day' (Suratil Tauba:29)

$$
\text { يا ايها الذين آمنو ا قاتلوا الذين يلونكم من الكفار فليجدوا فيكم غلظة }
$$

'Ooh you believers fight the people in your immediate neighbourhood among the disbelievers'(Suratil Tauba :123) 
All these verses refer to a specific class of non-Muslims and do not apply to all of them; it applies only to those who are at war with Muslims in the field as indicated in the verse where Allah clarified that He does not preclude Muslims form co-existing with those non-Muslims who have not fought Muslims because of their Muslim faith.( Suratil Mumtahina 8 -9)

لا ينهاكم الله عن الذين لم يقاتلوكم في الدين ---"

\section{Conclusion}

Islam recognizes plurality in faith and Allah alone takes charge to reward or punish people for exercising their freedom of choice. Islam condemned the societies that attempted to take away this right from people. Early Muslims attempted to take away this right from people by compelling them to follow the true way of Islam from the Muslim perspective, Allah precluded them from that, however this right is subject to the rights of others to a peaceful and healthy society and the right to respect their faiths and believe, therefore penalties could be provided for such violations. The early Muslim Jurists generally considered change of Muslim faith to any other faith a crime without restricting to specific violation of the rights of the society or others. This general averment is in consistent with the express provisions of the Holy Quran which guarantee freedom of faith and worship. The Prophetic Traditions in this regards although authentic, their narrations lack the context with some of them referring to the offense of Banditry and they could be construed against the background of war to form the law of war since Muslims were at war with non-Muslims and change of Muslim faith was tantamount to change of ranks in the battle field. Therefore in the context of peace the traditions are not applicable.

The understanding of the Prophet's companions that the traditions apply to all cases including even mere change of Muslim faith may be contested on the premises that the Opinion of Swahabah (Prophet's Companions) may not be an absolute authority, since the Companions challenged their own opinions; for instance Aisha, may Allah be pleased her, holding Abu Huraira to task for narrating a tradition condemning a Muslim woman to Hell fire for having denied a cat food and water occasioning its death. The Companions themselves changed their opinions; for instance after having understood that the Quran should be preserved through memorizing, they changed that view and opted to compile it in Quran. This means that we should revisit the provisions for Ridda in our Jurisprudence to exclude mere change of faith not accompanied with any breach of other duties. 


\section{References:}

1. Farooq Hassan. (2012). Islam: Religion of Tolerance or Terrorism (an analytical and critical study). International Journal of Contemporary Research in Business. Pakistan: Department of Humanities, University of Engineering \& Technology. Vol. 3 No 10

2. Dr. Ibrahim Abu Bakar, (2013). The Religious Tolerance in Malaysia: An Exposition. Malaysia: www.researchgate.net/publication/236336271 retrieved on March $4^{\text {th }}$, 2016

3. Isma'il bin Kathir, Abu al-Fida' (2006) Al-Sira al-Nabawiyya. Translated by Prof Trevor Le Gassick and reviewed by Dr. Muneer Fareed. UK: Garnet Publishing. Vol. 2 pg 7

4. Al-Kasani. (2002) Bada'i as-Sana'i. Beirut - Lebanon: Dar alKotob al-Ilmiyah Vol 9 pg 532

5. Marmaduke Pickthall.. (2016). Tolerance in Islam. Birmingham UK: Islamic Mission Dawah Centre

6. Muhammad ibn Ismaeel al-Bukhari. (2015). Sahih al-Bukhari. Translated by Muhammad Muhsin Khan. Riyadh KSA: Darussalam Publishers. www.darussalampublishers.com

7. Muslim ibn al-Hajjaj. (2015). Sahih Muslim. Translated by Nasiruddin al-Khattab Riyadh KSA Darussalam Publishers. www.darussalampublishers.com.

8. As-Sarkahsi. (undated) Al-Mabsout. Beirut- Lebanon: Dar alMarifa Vol 10 pg 108-109

9. Thowfeek M. I. M, Sri Lanka. Understanding Religious Tolerance in Islamic Perspective. American National College retrieved on March $4^{\text {th }}, 2016$

10. Dr. Zahid Aziz, Religious Freedom in Islam. www.ahmadiyya.org. retrieved on March $4^{\text {th }}, 2016$

11. Sulaiman bin Ash'ath. Abu Dawud. (2008). Sunan Abu Dawud. Translated by Nasiruddin al-Khattab. Riyadh KSA. Darussalam Publishers www.darussalampublishers.com 